\title{
O DESAFIO DE REPRESENTAR A ABEn NO CONSELHO NACIONAL DE SAÚDE
}

\author{
Maria Natividade Gomes da Silva Teixeira Santana*
}

o Sistema Único de Saúde -SUS, que consubstancia a maior política de inclusão social deste país e garante assistência saúde gratuita e de qualidade para todos os cidadãos, só se tornou viável, no Estado Brasileiro, por que tem como um dos seus pilares Constitucionais, o controle social.

A Associação Brasileira de Enfermagem-ABEn no cumprimento do seu papel na defesa da cidadania e das instituições democráticas, participa efetivamente na organização dos trabalhadores da área de saúde, em prol da implementação do SUS. Neste sentido, a ABEn teve atuação importante na construção e consolidação do Fórum de Entidades Nacionais dos Trabalhadores da Área de Saúde - FENTAS, um espaço democrático de discussão e pactuação de propostas para o fortalecimento das políticas públicas de saúde para o país, bem como fazer a sua defesa no Conselho Nacional, em concordância com os princípios e diretrizes do Sistema Único de Saúde-SUS, na forma da Constituição.

Esse Fórum, historicamente construído pelas entidades nacionais, tem tido relevante contribuição da $A B E n$, no fortalecimento do controle social, que culminou com o aumento das vagas dos trabalhadores no pleno do CNS, de duas, para oito vagas, recompondo o percentual de trabalhadores para cumprir a lei no que diz respeito à paridade de $25 \%$ para os gestores e prestadores em relação aos 50\% de usuários.

As representantes da ABEn, no FENTAS mereceram o reconhecimento e a confiança dos seus pares, sendo eleitas para representar os trabalhadores no Conselho Nacional de Saúde.

O trabalho ético, sério e competente desta entidade, fez com que a sua liderança entre os trabalhadores se estendesse ao CNS, e se consolidasse merecendo hoje o respeito dos segmentos que o compõem. É importante que se reporte à atuação das conselheiras representantes da ABEn, na organização das Conferências de Saúde, nas quais atuaram como membro de comissões, coordenaram mesas e contribuíram com palestras em eixos significativos.

Ressaltem-se as inúmeras representações do CNS, das quais se destacam a palestra no Seminário Internacional Sobre os Cuidados Primários de Saúde - 25 Anos de Alma-Ata, e as Conferências Temáticas de Vigilância Sanitária, Saúde Mental, Saúde Bucal, Assistência Farmacêutica e Medicamentos, Farmapolis, Ciência e Tecnologia, em que se levou a contribuição da ABEn, na organização e nas Mesas Redondas, painéis e conferências.

Várias foram as ações desencadeadas pela ABEn, que tiveram a adesão das entidades nacionais dos trabalhadores e levadas ao CNS, obtiveram aprovação dos conselheiros. Assim aconteceu com as Diretrizes Curriculares para a Educação Profissional de Nível Técnico, as Diretrizes para os Cursos de Graduação da área de saúde e da Educação Tecnológica em que as propostas da ABEn elaboradas coletivamente, conseguiram obter a adesão do FENTAS e o apoio do CNS e assim se sobrepor àquelas com as quais os segmentos envolvidos não concordavam.

A elaboração dos Princípios e Diretrizes para a Norma Operacional Básica de Recursos Humanos (NOB-RH) sob coordenação da Comissão intersetorial de Recursos Humanos para o SUS,-CIRH/CNS, hoje consolidada como Política Nacional de Gestão do Trabalho e da Educação para a Saúde, tiveram a contribuição decisiva da ABEn, em três Gestões consecutivas, desde 1995 até a sua homologação em 2002, sem prejuízo da contribuição de gestões anteriores, que participaram do ideário nas conferências Nacionais de Saúde e de Recursos Humanos, representando a posição da ABEn.

Importante também foi a contribuição da ABEn contra o PL 025/02 do Ato Médico, deflagrada no FENTAS, e denunciada no CNS, que se consolidou em âmbito nacional por meio dos conselhos de saúde dos estado e dos municípios, culminando com a rejeição do PL, na 12 Conferência Nacional de Saúde, cujo relatório aprovado pelo Pleno, ratifica a posição contrária a esse projeto de lei.

Ressalta-se a contribuição na elaboração da resolução 333/03 e mais recentemente da proposta de decreto de recomposição do Conselho, cujo teor rejeita a vaga cativa para as entidades médicas nos conselhos de saúde, representando um avanço na organização dos trabalhadores e na defesa da democracia; o que requereu intensa negociação com os usuários e gestores, na qual a participação da ABEn, foi determinante.

Inúmeras foram as contribuições no controle das Políticas Públicas, levadas ao CNS pelo governo federal, principalmente daquelas que dizem respeito à gestão do trabalho e da educação em que a CIRH formula pareceres para subsidiar o Pleno, no controle destas políticas.

É certo que todo este trabalho só é possível porque a ABEn trabalha em rede. A cooperação das Seções e das enfermeiras conselheiras estaduais e municipais propicia a retaguarda necessária e o apoio imprescindível para que este desafio de reafirmar o controle social do SUS e representar a ABEn no Conselho Nacional de Saúde, seja mais uma ação efetiva desta entidade que atua de forma proativa pela ética justiça e cidadania.

A renovação da representação do FENTAS no CNS está próxima, por isto, se faz necessária a concentração de esforços para que mais uma vez a ABEn seja eleita para representar os trabalhadores e assim continuar o trabalho já consolidado, com a competência e a firmeza necessárias que esta ação requer, e que esta entidade com muita honra sabe fazer.

*Enfermeira. Mestre em Educação. Conselheira Titular do Conselho Nacional de Saúde.

E-mail: marinati@terra.com.br 